\title{
Linking silvicultural aspects of pro-poor leasehold forestry for socio-economic benefits to the poor and vulnerable communities
}

\begin{abstract}
K. K. Yadavi* , G. P. Kafley² and K. P. Yadav ${ }^{3}$
Government of Nepal has adopted different models like community forestry, leasehold forestry, collaborative forestry, buffer zone community forestry and public land agroforestry for management of forest resources. Poor focused leasehold forestry is only the approach adopted since early 1990 that has two major objectives: livelihood improvement and environmental conservation. Forest user groups of 5-15 households (HHs) are provided with part of national forests for a period of initial lease of 40 years. Leased forests are managed mainly with forestry crops, forage and non-timber forest products (NTFPs) to meet the dual objectives. Past studies and researches have indicated that leasehold forests are better than the hand over time however they are inadequate in dealing with silvicultural aspects in leasehold forestry (LF). This research paper has highlighted the significance of silvicultural aspects of leasehold forestry for overall socio-economic benefits to the poor and vulnerable forest users. Review of the existing policy and legal documents, studies and progress reports of the leasehold forestry projects implemented during the last two decades, consultation with leasehold forest user groups from five districts (Tehrathum, Makawanpur, Tanahun, Pyuthan and Doti) formed the main source of data for this article. Further, author's own experiences in the sector were taken as supporting reliable information for the study. The study found that silvicultural practices, except plantations and weeding, were not adopted in leasehold forest but there was great potential for such practices to maximize the socio-economic benefits. Proper use of silvicultural practices might have increased contribution to currently realized benefits like (i) increased income of members i.e. poorest families (having less than 3 months secured foods) were reduced over years, (ii) group members had increased access to different networks and cooperatives, (iii) participation of women, poor and indigenous people increased in the decision-making process, and (iv) forest coverage was increased with respect to the hand over time. Some issues on silviculture aspects included proper guidelines for silvicultural methods, capacity of staff and leasehold forest user group members, smaller sizes of leasehold forests, and promotion of appropriate species.
\end{abstract}

Key words: Benefits, leasehold forestry, poor, silviculture, socio-economic, women

C ommunity based forest management modalities like community forestry (CF), collaborative forest management and leasehold forestry (LF) have been recognized by the Nepal's Forest Act 1993 and Forest Regulation 1995 (HMGN, 1993 and 1995). Out of these modalities, LF is only the modality which exclusively involves poor segments of forest dependent people. Poor focused LF implemented with dual goals of reducing national poverty and ameliorating the environment is spreading nationwide. The poor focused LF has been the priority (P1) programme of the Government of Nepal (GoN), which is based on the principles of the positive discrimination in favor of the people living below the poverty line (DoF, 2014).

The Master Plan for the Forestry Sector (MPFS) 1989 (HMGN, 1989) included the LF as a primary programme, however, that LF programme was conceptualized mainly for the supply of forest products for the wood-based industries, in other words the MPFS focused to lease the forests to private sectors. Later, the LF for the poor was

${ }^{1}$ UNDP, Lalitpur, Nepal. *E-mail: yadav.forester@gmail.com

${ }^{2}$ Nepal Foresters' Association, Babarmahal, Kathmandu, Nepal

${ }^{3}$ Green Nepal, Lalitpur, Nepal 
included in the Forest Act 1993. Leasehold forest policy 2002 (MoFSC, 2002), approved by the GoN, has explicitly divided LF into LF for the people living below the national poverty line and LF for industry and institution and LF for ecotourism. The development plans such as the tenth five-year plan (2002-2007), interim plans (2007-2010, 2010-2013), thirteenth three year plan (2013-2016) and fourteenth three year plan (2016-2019) have considered and categorized the poor focused leasehold forestry programme as one of the priority programme of forestry sector to achieve the national objective of poverty alleviation and has been implemented in a larger scale.

At operational level, the poor focused leasehold forestry commenced with the launching of Hills Leasehold Forestry and Forage Development Project (HLFFDP) by the Department of Forests (DoF) in 1992 with financial assistance from International Fund for Agriculture Development (IFAD). After that other forestry projects namely, Livelihoods and Forestry Programme (LFP), Biodiversity Sector Programme for Siwaliks and Terai (BISEP-ST) and Western Uplands Poverty Alleviation Programme (WUPAP) also scaled up the concept. Further, the concept has also been mainstreamed into community forestry in the form of land allocation for a short period lease. Nationwide, there are 7,419 leasehold forest user groups (LFUGs) comprising 75,021 households (HHs) involved in utilizing the forest resources developed on their leased forests of about 42,835 ha, initially of low productivity, for their sustainable livelihoods (DoF, 2014). Currently, the DoF has been implementing the leasehold forestry programme using government's own fund.

In the process of forest hand over, the HHs in each LFUG below the national poverty line are organized in a small group of 5-15 HHs. Participatory well-being ranking process is followed by the DoF staff with active participation of the local communities and priority is given to women, Dalits (untouchables), Janajatis (indigenous) and other excluded HHs (DoF, 2009). District Forest Officers (DFOs) hand over a part of national degraded forests to LFUGs on lease for first 40 years' tenure, with possibility of extending the lease period for another 40 years and lease fee is waived for these poor groups (MoFSC, 2002). In terms of species composition, leasehold forests are developed with combination of forest crops and forage crops in the ratio of $70 \%$ and $30 \%$, respectively, thus the model results into an agroforestry - Silvo-pastoral system as the objective of promoting forage crops is to support the forest users for livestock rearing.

Forests below 20\% crown cover are generally handed over to the groups. The LFLP Baseline Study 2006 showed that the lease land has poor vegetative cover; about $92 \%$ of the leased land has less than $20 \%$ coverage whereas $5.7 \%$ has $21-50 \%$ vegetative cover at the hand over time (DoF, 2006). However, the forests have grown over time and forest conditions have improved. Experiences, results and achievements from the last 25 years of leasehold forestry have shown positive and commendable contribution in reducing the national poverty and in ameliorating the environment. Different studies (DoF, 2006; FAO, 2011; FAO, 2012; FAO, 2014; Ohler, 2000) have indicated that forest conditions inside the leasehold forests have improved as compared to the hand over time. However, these studies have not described about the silvicultural practices inside LF and their significances; only plantation, weeding and collection of forage and fuel wood from the leasehold forests have been explored, which has formed a big knowledge gap. With assumptions that the benefits from the LF can be maximized if proper management of leasehold forests, especially for forest crops, is undertaken adopting silvicultural options. This paper has tried to link the silvicultural systems with socioeconomic benefits for pro-poor.

Leasehold forests are handed over to the forest dependent poor people for uplifting their socioeconomic benefits. The forests having crown cover up to $20 \%$ are identified and handed over to the LFUGs who grow both forest and forage crops. The LF management guideline recommends for planting forest and forage crops in the ratio of $70 \%$ to $30 \%$ (DoF, 2009). The latter is mainly encouraged to produce forage/grasses for rearing goats and other livestock to raise farmers' income. Thus, silvo-pastoral based agroforestry modality has been adopted in LF and this model of silvopastoral system of agroforestry model has been proved to be a scientific model. 


\section{Materials and methods}

\section{Study area}

Ten sample LFUGs, two each from Tehrathum, Makawanpur, Tanahun, Pyuthan and Doti districts, were selected for the research purpose. Focus group (members of LFUG committees including women) discussions were held in each sample LFUG and bio-physical information of forests were collected. Existing policy and legal documents, studies, progress reports and database of leasehold forestry projects implemented during the last two decades and other related literatures/ articles available were reviewed. The staff of the DoF working in leasehold forestry as well as regional and districts were consulted to integrate their experiences and learning into this study. The authors' experiences in the LF were also taken as sources of information for the paper.

\section{Results and discussion}

\section{Leasehold forest management: Existing practices and silviculture}

Majority of the leasehold forests are in open and degraded land having less than $20 \%$ crown cover (DoF, 2006) and thus, LFUG members' first task becomes to raise forest and forage coverage inside their leased plots. The study found that major species inside the leasehold forests were: Simal (Bombax ceiba), Barro (Terminalia belerica), Chilaune (Schima wallichii), Karam (Adina cordifolia), Bakaino (Melia azedarach), Siris (Albizzia spp.), Ipil Ipil (Leucaena spp.), Sal (Shorea robusta), Pines (Pinus spp.), Asna/Saj (Terminalia alata), Bhimal (Grewia optiva), Lankuri (Fraxinus floribunda), Khair (Acacia catechu), Dabdabe (Garuga pinnata), Amala (Phyllanthus emblica), Amriso - Broom grass (Thysanolaena maxima), Napier, Masala (Eucalyptus sp.). Among these, multipurpose and forage species like Bhimal, Ipil Ipil, Broom grass and Guila were planted by the groups. For forage and grasses, Stylo, Molasses, Napier and other grasses were planted as well.

The LFUG members were trained on leased forest land development and the training included sessions to orient members on raising forest crops and forage species. A-Frame was introduced to plant forest/forage crops along the contour line on the hill slopes to protect land from soil erosion. The trainings also oriented the members on selection of good mix of forage and forest species. Table 1 shows that, $70 \%$ of leasehold forests had increased number of species compared to the hand over time, the results are in line with the

Table 1: Species composition in leasehold forests

\begin{tabular}{|c|c|c|c|c|c|c|}
\hline S.N. & LFUG Name & $\begin{array}{l}\text { Hand } \\
\text { over year }\end{array}$ & District & $\begin{array}{l}\text { Species at hand } \\
\text { over time }\end{array}$ & $\begin{array}{l}\text { Species now (at study } \\
\text { time) }\end{array}$ & Changes \\
\hline 1. & Simalgauri "Ga" & 2007 & Tanahu & $\begin{array}{l}\text { Simal, Barro, } \\
\text { Chilaune }\end{array}$ & Simal, Barro, Chilaune & no \\
\hline 2. & Ghusi Tole & 2006 & Tanahu & Karam & $\begin{array}{l}\text { Bakaino, Thotne, Siris, } \\
\text { Ipil }\end{array}$ & 4 new \\
\hline 3. & Gajlat & 2006 & Doti & Sal, Pines & $\begin{array}{l}\text { Bakaino, Sal, Pines, } \\
\text { Ipil }\end{array}$ & 2 new \\
\hline 4. & Badhane Mandir & 2008 & Doti & Sal, Pines & $\begin{array}{l}\text { Sal, Pines, Asna/Saj, } \\
\text { Bhimal }\end{array}$ & 2 new \\
\hline 5. & Ujjwaal & 2005 & Makawanpur & Sal, Asna, Khair & Sal, Asna, Khair & no \\
\hline 6. & Sarsawati & 2005 & Makawanpur & Sal, Asna & Sal, Asna & no \\
\hline 7. & Arnachaur & 2010 & Pyuthan & $\begin{array}{l}\text { Salla, Lankuri, } \\
\text { Utis }\end{array}$ & $\begin{array}{l}\text { Lankuri, Utis, } \\
\text { Bamboo, Dabdabe, } \\
\text { Chilaune }\end{array}$ & 3 new \\
\hline 8. & Dhuwaghat & 2006 & Pyuthan & $\begin{array}{l}\text { Utis, Tiju, } \\
\text { Chilaune, Salla, } \\
\text { Amala }\end{array}$ & $\begin{array}{l}\text { Utis, Tiju, Chilaune, } \\
\text { Salla, Amriso, Napier }\end{array}$ & 2 new \\
\hline 9. & Padepakha Women & 2002 & Tehrathum & Utis & Utis, Pines & 1 new \\
\hline 10. & Sanishchare & 2003 & Tehrathum & Utis, Chilaune & Masala, Utis, Chilaune & 1 new \\
\hline
\end{tabular}


past findings (Ohler, 2000; NPC, 2005 and Yadav et al., 2014). According to Ohler (2000), species diversity of leasehold forest increases steadily over time ( $57 \%$ and $86 \%$ increases over $5-6$ years recorded). The leasehold forest also becomes more structured, multi-layered, and develops a good ground cover, increasing from $32 \%$ in new LFUGs to $78 \%$ in 6 to 7 years old LFUGs.

The LFUGs receive Patta (lease certificate) from the respective District Forest Officer and then LFUGs prepare their Operational Plans (OPs) with technical support from the District Forest Office. Review of the OPs of the ten LFUGs from different regions revealed that the OPs were more focused on plantation of forage and forest species including NTFPs. Silvicultural aspects or tending operations were hardly mentioned in any of the OPs.

Weeding and plantations were the main forest management activities being carried out by the LFUGs. Based on the ten sample LFUGs from five districts, trends of both weeding and plantation were found to be increasing over time (weeding: $50 \%$ in $2012 / 13$ to $80 \%$ in $2014 / 15$ plantation: $40 \%$ in $2012 / 13$ to $60 \%$ in $2014 / 15$ ) (Fig. 1).

\section{Trend of LF Management Activities}

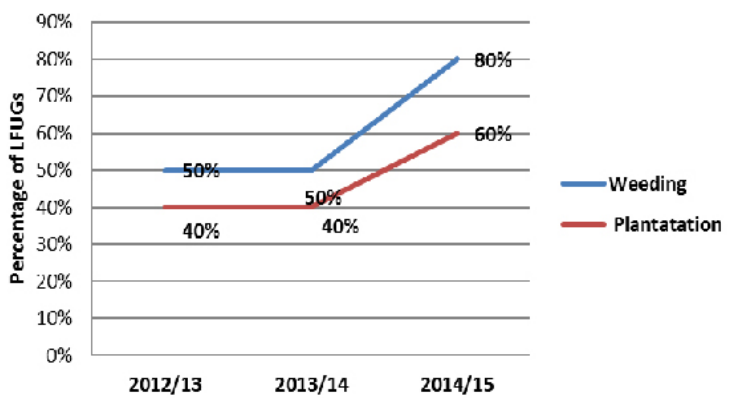

Fig. 1: LF Management activities

These findings are similar to the earlier studies (FAO, 2012, Yadav et al., 2014, and FAO, 2014) in which the percentage of the LFUGs carrying out weeding and plantation were $28 \%$ and $23 \%$ in 2007/08 and $65 \%$ and $49 \%$ in 2013.

Thus, current management practices of LF management have not emphasized the silvicultural systems though users have practiced knowingly or unknowingly few tending operations like weeding and cleaning. The LFUGs do plantations inside the LFs and the trend of plantation is increasing over time.

The DoF has developed a guideline and training manuals that guide LFUG members and forest technicians for carrying out leased forest land development activities such as plantation of forest crops and forage crops, balancing their composition ratios, plantations, etc. However, these guidelines do not clearly provide guidance for silivicultural treatments or operations to be carried out in the LFs. Consultations with the staff and facilitators (Group Promoters, LF Rangers, Assistant Forest Officers, Experts) revealed that the staff and local resource persons were not trained specifically on silivicultural practices inside the LF. However, they agreed that these practices inside LF would benefit the forest users. Some guidelines/manuals developed e.g. Lopping guidelines in 2012/13 but they were not in use.

\section{Changing crown cover and future scope of silvicultural practices inside leasehold forests}

Contexts of LF have changed with respect to the start of the concept in 1992. Many changes are visible on the ground; leasehold forests handed over in the beginning consist of mix of regeneration, poles and trees. These leasehold forests have enough potential to accrue additional benefits to the LFUG members because health of the forests is improving.

Out of the ten sampled leasehold forests, six leasehold forests had less than $25 \%$ crown cover

Table 2: Leasehold forest cover change over time

\begin{tabular}{cccccc}
\hline $\begin{array}{c}\text { No. of leasehold forests by } \\
\text { crown cover category (\%) at } \\
\text { hand over time }\end{array}$ & $\begin{array}{c}\text { No. of leasehold forests by crown cover } \\
(\%) \text { category in } \mathbf{2 0 1 5}\end{array}$ \\
\cline { 2 - 6 } & 6 & 0 & 3 & 3 & 0 \\
\hline $0-25$ & 3 & 0 & 2 & 1 & 0 \\
$26-50$ & 1 & 0 & 0 & 1 & 0 \\
$51-75$ & 0 & 0 & 0 & 0 & 0 \\
$>75$ & $\mathbf{0 - 2 5}$ & $\mathbf{2 6 - 5 0}$ & $\mathbf{5 1 - 7 5}$ & $>\mathbf{7 5}$ \\
\hline Total & $\mathbf{1 0}$ & $\mathbf{0}$ & $\mathbf{5}$ & $\mathbf{5}$ & $\mathbf{0}$ \\
\hline
\end{tabular}


at the time of hand over but three of them were shifted into $25-50 \%$ and the remaining three into $50-75 \%$ crown cover category (Table 2 ). These findings are similar to the past studies. Yadav et al. (2014) found that the leasehold forests having less than $25 \%$ crown cover at the time of hand over have graduated into upper categories i.e. more than $25 \%$ crown cover. Similar findings were found by FAO, 2012 and FAO, 2014 during outcome monitoring surveys. Some of the leasehold forests need silvicultural practices now whereas some need silvicultural practices in near future to maximize benefits to the users.

The leasehold forests had poles and trees at the time of hand over and they have now become either at exploitable size or are in need of management. The leasehold forests of Shaktikhor in Chitwan and some in Doti have Sal (Shorea robusta) as major species and they have reached at pole stage which need tending operations for their proper growth and development (field observation by Author in 2012).

By applying the silvicultural practices, not only the condition of the forests will be improved but it will also give more socio-economic benefits to the poor and vulnerable communities. NPC (2005) found that there was substantial improvement in the condition of forests both in area coverage (area and crown) and composition (density, quality, types and species diversity). The zero grazing approach has made all the area conducive for natural regeneration and enrichment plantation. Ninety-five per cent of households had practiced stall feeding with less than one month free grazing. Most of the forestbased income generating activities, especially herbal plants production and establishment of leguminous forage species, were not successful in most of the sites due to poor site conditions and lack of technical backstopping.

Pandit (2009) found that on an average, 69\% of the leased land was almost without trees, grass or other species (degraded land - 95\%) at the time of hand over. The LF has positive results for environmental conservation in many ways: increased regeneration, increased green ground coverage, increased crown density, increased biodiversity, reduced pressure on national forests for fuel wood and fodder, awareness increase in organic fertilizers use, developed greenery in shifting cultivation areas (CRFD, 2010).
Leasehold forestry contributing for socioeconomic capital formation

The LF has provided an extended benefit of social cohesion and networking for the poor involved in the process. Women, Dalits, Janajatis and poor households have become more capacitated to lead the process. Especially women and Dalits who had great hesitation to speak with people (field discussion, 2015) and put forward their needs, are now leading the groups; they can speak with visitors and they can access services and benefits from other support organizations as well. Yadav et al. (2014) found that the participation of women and poor in the LFUG committees and decision making positions increased over the time. The findings showed that proportions of women and the poorest in LFUG committees had increased from $39 \%$ to $42 \%$ and $22 \%$ to $30 \%$, respectively for a period of 2010 to 2013 .

The LFP has adopted the concept of building economic capital of the users starting from goat rearing. Goats were distributed to each $\mathrm{HH}$ and forage production was expected to support goat rearing and graduating towards cattle rearing. The average size of goat herd was increased from three goats per $\mathrm{HH}$ at hand over time to six goats per HH in 2014. This study showed the size of goat herd was increased from 3.1 goats per $\mathrm{HH}$ to 5.5 goats per HH. Further, each LFUG member saved in a range of Rs. 5 to Rs. 50 or more in group's saving credit scheme. About $97 \%$ of the LFUGs had saving/credit scheme and $91 \%$ of members had saved on a monthly basis. Monthly saving rate per $\mathrm{HH}$ was also increased from NRs 18 to NRs 25 between 2010 and 2014. About $77 \%$ of saved amount was mobilized within the groups as soft loans. Further, the LFUGs were associated with cooperatives, each cooperative (Rural Finance Associations) consisting of 10-15 LFUGs. LFUG members had increased access to financial services i.e. soft loan. Such soft loans were being mobilized within the poorest households for increasing their household income.

\section{Leasehold forests benefiting the poor and vulnerable communities}

The LFP has been adopted to uplift their socioeconomic status and at the same time to increase environmental conservation through their active participation. The impacts are now visible and poor people are benefitted from the leased forests, 
which ultimately contributes toward reducing national poverty. Though all the LFUG members were poor, they were further categorized into poor, poorer and poorest. The proportion of poorest households was found to be decreased over years. Yadav et al. (2014) found that the proportions of poorest $\mathrm{HHs}$ in LFUGs were $41.4 \%, 29 \%, 23 \%$ and $19 \%$, respectively in 2006 , 2010, 2011 and 2013. These changes are partly contributed by the LF activities and depend on the way forest resources are managed. Thus, silvicultural practices have great potential to diversify livelihood options for poor HHs.

\section{Issues, concerns and way forward}

From this study it is found that the LF has been fruitful in achieving dual objectives of environmental conservation and poverty reduction. The results and achievements are commendable as these are being obtained in the scenario where silvicultural aspects are not considered and followed. The following subsections provide some issues and concerns along with the actions that could be taken as ways forward.

Review and revision of LFUG OPs: LFUG OPs do not cover in detail the silvicultural aspects to be followed by the group members. It merely describes about plantation of tree species and forage crops. So, review and revision of OPs of the LFs which have potential of management could be done in phase-wise basis.

Capacity building: Capacities of both LFUG users and staff are to be enhanced through trainings, workshops and exposures. Technical staffs of DFOs have been capacitated with the technical prescriptions and their applications in the field and they are doing for community forests (including land allocation practices), national forests, public land agroforestry, etc. They should be oriented to apply their knowledge and skills in revising LFUGs OPs and practice inside the LFs. Similarly, the capacities of LFUG members and local resource persons need to be enhanced with trainings, orientations and exposure visits to the $\mathrm{CFs}$, national forests where such practices have been done.

\section{Conclusion}

This paper found that overall condition of leasehold forests is improving over time and the LFUG members are benefiting from it. However, silvicultural aspects of leasehold forest management are not adequately addressed in practices, technical capacities of staff and communities are to be enhanced. It concludes that socio-economic benefits for poor are linked with the products obtained from LF and so, LF management should be promoted inside Leasehold Forests.

\section{References}

CRFD. 2010. Annual Monitoring and Evaluation Report 2010. Central Region Forest Directorate, Ministry of Forests and Soil Conservation, Kathmandu, Nepal.

DoF. 2014. Regional Workshop on Pro-poor Leasehold Forestry (eds.) K.C. Rajendra, Baral, J. C. and Kafley, G.P., 11-13 June, 2014, Kathmandu. Department of Forests, Kathmandu, Nepal.

DoF. 2009. Programme Implementation Guidelines. Leasehold Forestry and Livestock Programme, Babarmahal, Kathmandu, Nepal.

DoF. 2006. Baseline Report. Leasehold Forestry and Livestock Programme. Department of Forests, Kathmandu, Nepal.

FAO. 2014. A Synthesis of Project Progress 20102013. Technical Assistance for Leasehold Forestry and Livestock Programme, FAO, Nepal.

FAO. 2014. An Assessment of Outcome of Leasehold Forestry and Livestock Programme 2013. Technical Assistance for Leasehold Forestry and Livestock Programme, FAO, Nepal.

FAO. 2012. An assessment of performance of LFUGs: LFUGs stratification. Technical Assistance for Leasehold Forestry and Livestock Programme, FAO, Nepal.

FAO. 2011. An Assessment of Outcome of Leasehold Forestry and Livestock Programme 2010/11. Technical Assistance for Leasehold Forestry and Livestock Programme, FAO, Nepal.

MoFSC. 2002. Leasehold Forest Policy 2002. Ministry of Forests and Soil Conservation, (MoFSC) Kathmandu, Nepal. 
HMGN. 1995. Forest Regulation 1995. Ministry of Forests and Soil Conservation, Kathmandu, Nepal.

HMGN. 1993. Forest Act 1993. Ministry of Forests and Soil Conservation, Kathmandu, Nepal.

HMGN. 1989. Master Plan for the Forestry Sector (MPFS) 1989. Ministry of Forests and Soil Conservation, Kathmandu, Nepal.

MoFSC. 2007. Forest Sector Gender and Social Inclusion Strategy. Ministry of Forests and Soil Conservation,(MoFSC) Government of Nepal, Kathmandu, Nepal.

NPC. 2005. Impact Evaluation of Hills Leasehold Forestry and Forage Development Project (HLFFDP). National Planning Commission, Kathmandu, Nepal.
Ohler, Frits M. J. 2000. Impact of Leasehold Forestry on Livelihoods and Environment. Technical Assistance Phase 2 to Hills Leasehold Forestry and Forage Development Project (GCP/NEP/052/NET), FAO, Nepal.

Pandit, B. H. 2009. Effectiveness of Leasehold Forestry to Poverty Reduction. A Study Report for Technical Assistance for Leasehold Forestry and Livestock Programme, Food and Agriculture Organization of the United Nations, Nepal.

Yadav, K. K, Kafley, G. P., Hancock, J. and Shono, K. 2014. Results and impacts of Leasehold Forestry for enhancing livelihoods of poor farmers in mid-hills of Nepal. In Pro-poor Leasehold Forestry (eds.) K. C. Rajendra, Baral, J. C. and Kafley, G. P., Regional Workshop on Pro-poor Leasehold Forestry, 11-13 June, 2014, Kathmandu. Department of Forests, Kathmandu, Nepal, 209-220. 